\title{
A REVIEW ON GARBHOTPATI: DIFFERENCE BETWEEN NATURAL CONCEPTION AND ART
}

\author{
Meera Indukumar Rajani *1, Ami Vrujlal Rajani ${ }^{2}$ \\ ${ }^{1}$ Lecturer, Department of Streeroga \& Prasutitantra, Government Akhandanand Ayurveda college, Bhadra, Ahmedabad, \\ Gujarat, India \\ ${ }^{2}$ Lecturer, Department of Sharira Kriya, Government Akhandanand Ayurveda college, Bhadra, Ahmedabad, \\ Gujarat, India
}

Received on: 11/04/17 Accepted on: 25/05/17

*Corresponding author
E-mail: drmeerarajani@rediffmail.com

DOI: $10.7897 / 2277-4343.083160$

\begin{abstract}
For procreation of healthy, divine, immense offspring, Ancient Ayurveda Aacharyas have stated four essential factors known as Garbhasambhava samagree. If These factors remain in their unregenerated, natural form during garbhanirmana, the procedure would remain near to nature and antenatal perinatal period become uneventful. If any manipulation, alteration, adulteration done in any of these four factors, will lead to physical, psychological and functional deformity to the fetal outcome. In recent days, many infertile couples taking shelter under ART (Assisted reproductive technique) like IVF or ICSI. Several studies have indicated that infants conceived via ART are at higher risk for prematurity, low birth weight, at higher prevalence of congenital malformation, neural tube defects etc. The motive of this paper is to understand four essential factors for procreation of physically, mentally, spiritually and socially healthy offspring. Any alteration in these four factors leads to health hazards in perinatal, postnatal, childhood and in adulthood period as well.
\end{abstract}

Key words: Garbha, Garbha sambhava samagree, ART, IVF, Fetal outcome.

\section{INTRODUCTION}

The procreation is the noblest gift of almighty to human being. For this creation divine science like Ayurveda has stated some rules, rituals and regimens, by following which, the noblest procedure turns into the noblest outcome i.e. fetus. A lag on the part of any of nature's sequences, may lead to irreparable damage. One of the best examples is ART. The use of assisted reproduction technology (ART) has risen substantially and it is estimated that around 5 million babies in the world have been born since the first IVF baby in $1978^{1}$. India has recorded probably the highest growth in ART centers and the number of ART cycles performed. It has steadily risen over the last decade $^{2}$. In the light of these fact, it is evident that the proportion of children conceived through ART is not negligible and will influence the coming generations. Hence, it is important to monitor the consequences of manipulating gametes and embryos during ART.

The adverse perinatal outcome after ART is well-known. Elective single embryo transfer (eSET) has to a large extent abolished the problems associated with multiple pregnancies. However, eSET is not the only solution to the adverse perinatal outcome, as growing evidence has shown that even in singletons, ART is associated with an increased risk of preterm birth, low birthweight, very low birthweight, hypertensive disorders of pregnancy, antepartum haemorrhage, premature rupture of membranes, caesarean section, congenital malformations and cerebral palsy, when compared with singletons from spontaneous conceptions ${ }^{3}$.

A study observed a 2 fold increase risk of major birth defects among children conceived via conventional IVF or ICSI, compared to that in a matched population of children who were naturally conceived ${ }^{4}$. Some also have suggested that altered epigenetic programming of gene expression in pregnancies resulting from ART may adversely affect fetal growth ${ }^{5}$. Preliminary Data suggest that the prevalence of Angelman syndrome (mental retardation, delayed motor development, poor balance, abnormal movement, absent speech) and Beckwithwidemann syndrome (macrosomia, macroglossia, midline abdominal wall defects, predisposition to embryonal cancers) both resulting from imprinting defects may be increased in children born after $\mathrm{ART}^{6}$.

The origin of this adverse perinatal outcome may be due to following factors: hormonal stimulation, culture media composition, duration of embryo culture, IVF/ICSI technique and freezing/thawing techniques. A major concern is whether the IVF techniques themselves could have negative impacts on the ART offspring. For evaluating these negative outcome of IVF, it is necessary to introspect that which factors are responsible for healthy prenatal, perinatal and postnatal outcome. Aacharyas have given a unique definition of garbha (Embryo) and also of four factors, which are essential for procreation of garbha known as Garbhasambhava samagree (Factors essential for conception).

The union of shukra (spermatocyte), shonita (oocyte) and jiva (soul) inside the uterus is known as Garbha (Embryo) ${ }^{7}$. In this definition each word has its own significance. Shukra (Spermatocyte) is saumya (Soft) in nature and carrying its own property during impregnation. Shonita (oocyte) having Aagney (fiery) property and having characteristic of rakta dhatu (blood), only this characters form fetus. Inside world is most important, in vivo atmosphere becomes favorable for arrival of Aatma (Soul) at that time. In the classics, for this union, some rituals, method of conjugation and its prior act are described. Acharyas opine, After completion of panchakarma therapy(purification of body), the man proper oleated with ghrita, having observed 
celibacy for one month ,after taking Sali rice with ghrita and milk in afternoon should have coitus in the night with the woman ,properly oleated with oil, having observed chastity for one month and taken food prepared with oil and Masha (black gram). ${ }^{8}$ Acharya kashyapa denies dawn -twilight time for coitus. ${ }^{9}$ By following these ritual shukra (Spermatocyte) and shonita (Oocyte) may become more sharpen to their characteristic and the area were implantation and development of fetus take place becomes immaculate.

\section{Garbhasambhava saamagree(Factors essential for conception)}

For having good crop in the field, 4 basic elements are necessary, such as seed, season soil, water. Similarly, for suprajanana i.e. for conception, Rutu (proper time for ovulation), kshetra (uterus), Ambu (nutritive substance), Bija (Gamets) are necessary ${ }^{10}$

\section{Rutu}

Rutu means appropriate time, appropriate age for conception. As the seeds deposited during this period are likely to bear wholesome fruits. The period of maximum fertility extends for twelve to sixteen days after menstruation during reproductive age During this period ovulation occurs spontaneously ${ }^{11}$.

\section{Kshetra}

Aacharyas Dalhan says kshetra is well primed disease free endometrium. Kshetra means an area where shukra (Spermatocyte) enters. As a seed of paddy sown in well prepared fields results into good yields the unvitiated gametes when embedded in unvitiated kshetra leads into quality pregnancy. Nidation take place in uterus and healthy uterus allowing nutrition to the initial stage embryo ${ }^{12}$.

\section{Ambu}

Ambu is rasa dhatu (Liquid extraction) derived as end products of food digestion. The blood and intercellular fluid of endometrial tissues with required nutrients is quite helpful for nidation and further development. Main action of this rasa dhatu is Prinana, means satiating by proving all essential nutrient to any cell, here zygote $^{13}$.

\section{Beeja}

Beej means seeds,here shonita(oocyte)-shukra(spermatocyte) .Unvitiated, in preferred atmosphere and unaltered form of gametes turn in to wholesome fetus ${ }^{14}$.

Thus these factors are essential not only for proper nidation but also for healthy prenatal, perinatal, postnatal and infant period too. Aacharya vagbhatta-1 added other three components like Marga, Hridi and Vat. Marga means disease free genital track, hridi is illuminated pure controlled mind-conscious and unvitiated vata is necessary in the formation and development of fetus ${ }^{15}$.

So in Ayurveda time for conception, psychological condition during coitus, age of man-woman, some hymn recitation before coitus diet before coitus, all factors narrated here so, that procreation is huge responsibility to be carried out with extra care.

\section{DISCUSSION}

In definition of Garbha (embryo), it is very clearly indicated that the phenomenon of union of shukra (Spermatocyte), shonit (oocyte) and jiva (soul) should be inside the uterus. In oviparous animals the egg hatches outside of the body and is exposed to light. In mammals fertilization and the growth of the embryo in vivo occurs in the dark but in human IVF, these embryos are exposed to variable light sources and intensities. So this phenomenon is devoid from nature and obviously affects natural outcome.

In IVF technique four essential factors are manipulated and altered in the following manner

Alteration in Rutu(Ovulation time)

Proper time for fertilization and nidation are considered under rutu factor. For ovulation induction, so-called 'controlled' ovarian hyperstimulation, using maximum stimulation by exogenous gonadotropins, together with the gonadotropinreleasing hormone (GnRH) agonist long protocol. Potential detrimental effects of this approach with regard to oocyte quality, corpus luteum function and endometrial receptivity have been largely ignored. These factors might by themselves have a major impact on IVF outcome and should therefore be considered seriously. For ovulation induction GnRH agonist and antagonist medicines are given. Sometimes it develops ovarian hyperstimulation which has unfavorable effect on oogenesis, embryo quality and endometrial receptivity. In one IVF cycle generally more than 20 oocytes are retrieved. study reveals that more than ten oocyte retrievals per woman badly affects oocyte quality. Moreover, ovarian stimulation protocols have become extremely complex. The most prominent factor dictating IVF outcome appears to be the individual variability in ovarian response to stimulation. Multivariate regression models can predict low ovarian response ${ }^{16}$ (which seems to be related to ovarian aging $)^{17}$, whereas the ovarian hyperstimulation syndrome (OHSS) develops unexpectedly in most cases.

Regarding rutu factor, it is totally occupied by medicine and injectable. The natural function is totally replaced by exogenous gonadotrophin hormone. Sometimes continued stimulation with $\mathrm{GnRH}$ agonist desensitizes the pituitary gland referred to as "pseudomenopause"18. In addition, such profound stimulation results in abnormal luteal phase endocrinology, and its impact on endometrial receptivity.

\section{Alteration in Kshetra(Uterus)}

The natural incubator of the mammalian embryo, the uterus has been fine tuned for million of the years. Homeostatic measures are in place to provide an environment that changes little, despite an external environment that is often quite variable. To a large part the focus of environment control in incubator has been on temperature and $\mathrm{pH}$. In the body changes in osmolality, $\mathrm{pH}$ and temperature are generally small and gradually but in IVF system these excursions can be relatively large and rapid. Perturbations in vitro, not generally present in the vivo culturing in the uterus, may result to the stress to the embryo. Other environment factors like exposure to toxicants, the off- gassing of volatile compound exposure to electromagnetic field, exposure of light and generation of reactive oxygen species should also consider IVF outcome. ${ }^{19}$ In a several way light uses in IVF affect the embryo, there may be a direct effect where light stress the cell, activate stress genes or even damages DNA directly via ionization. Light may also indirectly affect cells by oxidation of components in the media or oil. Light has also been shown to induce production of hydrogen peroxide, a substance toxic to cells when media containing HEPES and iboflavin are exposed to light ${ }^{20}$.

Characteristics of the surfaces used in ART (e.g. elasticity), of the devices used, such as Petri dishes and other parameters, such as $\mathrm{pH}$ and oxygen concentration, can also affect the embryos ${ }^{21}$ Oxygen tension is relatively low in oviduct and uterus in natural 
conception. While in ART it may vary. Changes of this environment afflicts epigenetic process also and affects birthweight. ${ }^{22}$

There is synchronization between endometrium and embryo in natural conception. The internal reproductive organs allow embryo for implantation only when endometrium is prepared for it and it is able to provide primary nutrition. This synchronization may get disturbed in the IVF cycle.

\section{Alteration in Ambu(Nutrition)}

Uterine histotroph and gland secretion include amino acids, ions, carbohydrates lipids, protein and likely other substance. They are presumed to be important mediators of uterine receptivity ,blastocyst implantation and conceptus growth. It is also a strange that commercially culture media are there to take place of maternal nutritive substances because ultimately culture medium is the foreign environment for the human embryo.

The culture medium in which an embryo is grown can have dramatic effects on development. From One of animal studies it is clear that culture medium constituents are responsible for birthweight changes in offspring. Various culture conditions, mainly associated with the addition of serum, have led to the socalled large offspring syndrome in sheep and cattle ${ }^{23}$ and to a reduced birth weight in mice. Also other types of in vitro stress upon the preimplantation embryo like a decrease in $\mathrm{pH}$, accumulating ammonium or different oxygen conditions can result in aberrant fetal growth in ART offspring ${ }^{24}$.

It is well known that early ruminant embryos also exhibit sensitivity to their environment which may, after transfer, lead to the condition of large offspring syndrome, characterized by aberrant fetal and placental development, increased fetal myogenesis, dystocia, abnormal perinatal pulmonary activity and increased mortality in the early postnatal period ${ }^{25,26} \mathrm{In}$ addition, some of the effects, such as increased organ size, can persist into later life ${ }^{27}$.

The first week after fertilization is characterized by precisely orchestrated events including the first mitotic divisions, zygotic genome activation, compaction, morula formation, cavitation and blastocyst formation. During these stages developmental programming takes place through timed epigenetic modifications ${ }^{28}$. This period is particularly sensitive and any epigenetic alterations that may give a survival advantage to the embryo facilitating its adaptation, can have irreversible consequences in gene expression and metabolic profile for the offspring and even for future generations. Furthermore, metabolism is linked to epigenetics through histone modification altered expression was detected after mouse embryo culture in Whitten's medium and in KSOM with AAs for 114 genes and 24 genes, respectively ${ }^{29}$. Also, suboptimal culture conditions led to impaired neuromotor development, behavioral abnormalities and anxiety in mice. The transgenerational adverse effects of a suboptimal culture environment, including lower weight to the time of weaning and larger organs during adulthood, were also documented ${ }^{30}$. There is evidence suggesting that embryo culture can also induce epigenetic alterations in human embryos demonstrated the impact that embryo culture can have on gene expression in different tissues by studying the methylation pattern for more than 700 genes from the placenta and the cord blood of ten ART conceived children compared with spontaneously conceived controls.

Alteration in $\mathrm{Bija}$ (Gametes):

Bija is most important factor amongst four. For fertilization acharyas have shown specific characteristic of shukra and shonita.shukra has quality like sfatikabham (white crystal like), dravam (liquid) snigdham (smooth),and artava is aagney (fiery) characteristics resembles with rakta dhatu(blood). With this specific characteristic shukra (Spermatocyte) enters the uterus and travels up to the fallopian tube and finally pierces the oocyte. The female genital passage helps in the ascending procedure and spermatozoa also become more strengthen. In IVF or ICSI these sequence breaks. Medication regimens to achieve profound ovarian stimulation are extremely complex and the optimal number of follicles that should be stimulated to maximize IVF outcome is still strange. In general, it is assumed that an increased quantity of oocytes is not at the expense of quality. However, the possibility that the stimulation of large numbers of follicles results in an increased percentage of chromosomally abnormal embryos. ${ }^{31}$

IVF treatment often require cryopreservation with subsequent thawing of gametes, embryos and ovarian tissue. Cryopreservation of spermatozoa cause these cells to lose their defenses. The freeze-thawing process seems to leave the female gametes more vulnerable to the detrimental effect of damage.

Oxidative stress is also real threat to gametes and embryo in vitro as these cells are removed from their natural environment. Due to oxidative stress during IVF on spermatozoa, lipid paroxidation, DNA fragmentation and Apoptosis occurs and meiotic spindle damage and reduction in quality of oocyte may appear. $^{32}$

\section{CONCLUSION}

In ART physiological milieu is simulated by modification of media, as well as the technique used. Embryo maternal communication exists in the periimplantation period with the female reproductive track providing the optimal microenvironment conducive to fertilization and the development of embryo. In vitro set up can never mimic the exact physiology of in vivo condition this leads to various detrimental consequences in fetus. It is the moral responsibility of a doctor to exercise the option of ART. If and only is the infertility cannot be cured by any medical or surgical treatment than only the ART should be considered. In such a scenario, also the patient should be clearly informed about the result and limitation of ART in black and white. Ultimately it affects the quality of upcoming generation and hence of the society at large.

\section{REFERENCES}

1. Dyer S., Chambers GM, de Mouzon J, Nygren KG, ZegersHochscild Mansour R, Ishihara O, Banker M, Adamson GD, International committee for monitoring ART world report assisted Reproductive Technology,2008,2009,2010.

2. Narendra Malhotra, Duru shah,M anish Bankar, Journal of human reproductive sciences, assisted reproductive technology in India : A 3 year retrospective data analysis, review article, year 2013, volume 6,issue 4,page 235-240.

3. Clinical gynecologic endocrinology and infertility Leon Speroff and Marc A Fertz,p art 2,seventh edition, Indian edition page No 1251-1252.

4. Hansen M, Kurinczuk JJ,Bower C, Webb S,the risk of major birth defects after intracytoplasmic sperm injection and in vitro fertilization, New Engl J Med 346:725,2002.

5. Cetin I,cozzi V, Antonazzo P, Fetal development after assisted reproduction - a review ,placenta 24(suppl B): S104,2003.

6. Niemitz EL Feinberg AP, epigenetics and assisted reproductive technology : a call for investigation ,Am $\mathrm{j}$ hum Genet 74:599,2004. 
7. Agnivesha, charaka samhita, vidyotinee commentary by vd. kasheeenath pandey and vd gorakhnath chaturvedi, shareera sthana.4/5., chaukhambha bharati prakashan,reprint 1998.pg no.867.

8. Agnivesha,c haraka samhita, vidyotinee commentary by vd. kasheeenath pandey and vd gorakhnath chaturvedi, shareera sthana.8/4., chaukhambha bharati prakashan, reprint 1998.pg no.919.

9. Vruudhjivakeeyam tantra,kashyap samhita, written by pandit Hemaraja Sharma,shareer sthana. jaatisootreeyashareera /7,chaukhambha publication,reprint 2009,page no.81.

10. Sushruta, sushruta samhita of sushruta with Ayurvedatatvasandeepika commentary by vd.ambikadatt shashtree.shareera sthana 2/35, chaukhambha publication ,reprint,2005.pg no. 15 .

11. A text book of Obstetrics by V.N.K. Usha., vol 1, haukhmbha Sanskrit pratishthan,2012 first edition, pg no. 133 .

12. A text book of Obstetrics by V.N.K. Usha.,v ol 1,chaukhmbha Sanskrit pratishthan,2012 first edition ,pg no. 133

13. A text book of Obstetrics by V.N.K. Usha., vol 1 , chaukhmbha Sanskrit pratishthan,2012 first edition, pg no. 135

14. A text book of Obstetrics by V.N.K. Usha.,v ol 1,chaukhmbha Sanskrit pratishthan,2012 first edition, pg no. 136 .

15. Vagbhatta,Ashtanghriday,edited with the vidyotini Hindi commentary by kaviraja Atrideva Gupata, $14^{\text {th }}$ edition 2003,sharera sthana 1/8. Pg no.170.

16. Bancsi, L.F. et al. (2002) Predictors of poor ovarian response in in vitro fertilization: a prospective study comparing basal markers of ovarian reserve. Fertil. Steril. 77, 328-336

17. Beckers, N.G. et al. (2002)Women with regular menstrual cycles and a poor response to ovarian hyperstimulation for in vitro fertilization exhibit follicular phase characteristics suggestive of ovarian aging. Fertil. Steril. 78, 291-297

18. Magon N (October 2011), Gonadotropin releasing hormone agonists: Expanding vistas,indian journal of endocrinology and Metabolism

19. Bavister B D: Interaction between embryo and culture milieu,theriogenology,2000.53,619-629

20. Kimball O Pomeroy,Michael L.Reed,2013,the effect of light on embryo and embryo culture,SAGE Journals.

21. Swain J. Optimizing the culture environment in the IVF laboratory: impact of $\mathrm{pH}$ and buffer capacity on gamete and embryo quality. Reprod Biomed Online 2010;21:6-16.

22. Nelissen ECM, Dumoulin JCM, Daunay A, Evers JLH, Tost $\mathrm{J}$, van Montfoort APA, Placentas from pregnancies conceived by IVF/ICSI have a reduced DNA methylation level at the H19 and MEST diff erentially methylated regions Human Reproduction. 2013;28(4):1117-26.

23. P. Lonergan , T. Fair, D. Corcoran, A.C.O. Evans, Effect of culture environment on gene expression and developmental characteristics in IVF-derived embryos, Theriogenology 65 (2006)

$137-152$, www.journals.elsevierhealth.com/periodicals.

24. Deirdre L Zander-Fox.,Megan Mitchell,Jeremy G. Thompson,Michelle Lane ,Alteration in mouse embryo intracellular $\mathrm{pH}$ by DMO during culture impair implantation and fetal growth, july 8 ,2010 2010,DOI :http://dx.doi.org/10.1016/j.rbmo.2010.05.001

25. Walker SK, Hartwich KM, Seamark RF. The production of unusually large offspring following embryo manipulation: concepts and challenges. Theriogenology 1996;45:111-20.

26. Sinclair KD, Young LE,Wilmut I, McEvoy TG. In-utero overgrowth in ruminants following embryo culture: lessons from mice and a warning to men. Hum Reprod 2000;15(Suppl. 5):68-86.

27. McEvoy TG, Sinclair KD, Broadbent PJ, Goodhand KL, Robinson JJ. Post-natal growth and development of Simmental calves derived from in vivo or in vitro embryos. Report Fertile Dev 1998;10:459-64.

28. Cockburn K,Rossant J, making the blastocyst :lessons from the mouse, doi:10.1172/JCI41229.Epub2010.apri 1

29. Thompson J, Kind K, Roberts C, Robertson S, Robinson J. Epigenetic risks related to assisted reproductive technologies: short- and long-term consequences for the health of children conceived through assisted reproduction technology: more reason for caution? Hum Reprod 2002;17:2783-2786.

30. Mahsoudi B, Li A, O’Neill C. Assessment of the long-term and transgenerational consequences of perturbing preimplantation embryo development in mice. Biol Reprot 2007;77:889-896.

31. Macklon,N.S.,JPM Geraedts,BCJM Fauser-Conception to ongoing pregnancy: the 'blackbox' of early pregnancy loss. Hum. Reprod. Update 8, 333-343.

32. Kowaltowski,AJ, verseci AE, mitochondrial damage induced by oxidative stress,free redcl.,boil,med,26,463471(1999).

\section{Cite this article as:}

Meera Indukumar Rajani and Ami Vrujlal Rajani. A Review on Garbhotpati: Difference between natural conception and art. Int. J. Res. Ayurveda Pharm. 2017;8(Suppl 3):4-7 http://dx.doi.org/ $10.7897 / 2277-4343.083160$

Disclaimer: IJRAP is solely owned by Moksha Publishing House - A non-profit publishing house, dedicated to publish quality research, while every effort has been taken to verify the accuracy of the content published in our Journal. IJRAP cannot accept any responsibility or liability for the site content and articles published. The views expressed in articles by our contributing authors are not necessarily those of IJRAP editor or editorial board members. 